\title{
UPAYA MENINGKATKAN KETERAMPILAN MENULIS KARANGAN NARASI MELALUI METODE QUANTUM WRITING PADA SISWA KELAS V UPT. SD NEGERI 04 SARUASO
}

MUKHLIS

mukhlis04@gmail.com

\begin{abstract}
This study aims to improve the narrative essay writing skills of the fifth grade students at UPT. SD Negeri 04 Saruaso through the quantum writing method of learning. This type of research is Classroom Action Research (PTK) with the Kemmis and McTaggart model. The stages carried out in this study include planning, implementing actions, observing, and reflecting. The subjects of this study were students of class V UPT. SD Negeri 04 Saruaso, totaling 23 students, namely 13 female students and 10 male students. This research was conducted in 2 cycles and each cycle consisted of 3 meetings. The data collection techniques used were tests, interviews, observation, and documentation. The data analysis technique used is quantitative data analysis and qualitative data analysis. The results of this classroom action research indicated an increase in writing narrative essay skills in the UPT V class students. SD Negeri 04 Saruaso uses the quantum writing method. This is indicated by the achievement of the class average score when writing narrative essays increasing from pre-action to cycle I and cycle II. The average score of writing narrative essays in the pre-action was 68.39 to 74.74 in the first cycle and 81.91 in the second cycle. The level of student completeness in writing narrative essays increased from the initial conditions of $39.13 \%$ to $65.22 \%$ in the first cycle and to $86.96 \%$ in the second cycle. Efforts to improve narrative essay writing skills using the quantum writing method are carried out with learning stages such as: delivery of material by the teacher, writing preparation, making drafts / outline essays, sharing writing with friends, correcting writing errors, editing written results, rewriting essays, and the teacher and students evaluate the narrative essay that has been produced.
\end{abstract}

Keywords: Writing skills, narrative essays, quantum writing learning methods.

Abstrak: Penelitian ini bertujuan untuk meningkatkan keterampilan menulis karangan narasi siswa kelas V di UPT. SD Negeri 04 Saruaso melalui metode pembelajaran quantum writing. Jenis penelitian ini adalah Penelitian Tindakan Kelas (PTK) dengan model Kemmis dan McTaggart. Tahap-tahap yang dilakukan dalam penelitian ini meliputi perencanaan, pelaksanaan tindakan, observasi, serta refleksi. Subjek penelitian ini yaitu siswa kelas V UPT. SD Negeri 04 Saruaso yang berjumlah 23 siswa, yakni 13 siswa perempuan dan 10 siswa laki-laki. Penelitian ini dilaksanakan dalam 2 siklus dan masing-masing siklus terdiri dari 3 pertemuan. Teknik pengumpulan data yang digunakan adalah tes, wawancara, observasi, dan dokumentasi. Teknik analisis data yang digunakan adalah analisis data kuantitatif dan analisis data kualitatif. Hasil penelitian tindakan kelas ini menunjukan adanya peningkatan keterampilan menulis karangan narasi pada siswa kelas V UPT. SD Negeri 04 Saruaso melalui metode quantum writing. Hal ini ditunjukan dengan pencapaian nilai rata-rata kelas saat menulis karangan narasi meningkat dari pra tindakan ke siklus I dan siklus II. Nilai rata-rata menulis karangan narasi pada pra tindakan sebesar 68,39 menjadi 74,74 pada siklus I dan mencapai 81,91 pada 
siklus II. Tingkat pencapaian ketuntasan siswa dalam menulis karangan narasi meningkat dari kondisi awal 39,13\% menjadi $65,22 \%$ pada siklus I dan menjadi $86,96 \%$ pada siklus II. Upaya meningkatkan keterampilan menulis karangan narasi menggunakan metode quantum writing dilakukan dengan tahap-tahap pembelajaran seperti: penyampaian materi oleh guru, persiapan menulis, membuat $d r a f t / k e r a n g k a$ karangan, berbagi hasil tulisan dengan teman, memperbaiki kesalahan penulisan, menyunting hasil tulisan, menulis kembali karangan, serta guru bersama siswa melakukan evaluasi pada karangan narasi yang telah dihasilkan.

Kata kunci: Keterampilan menulis, Karangan narasi, Metode pembelajaran quantum writing.

\section{A. Pendahuluan}

Bahasa memiliki peran penting bagi seorang individu dalam berkomunikasi dan berinteraksi dengan individu lain. Penguasaan bahasa yang baik akan membuat individu tersebut mampu berbagi pengalaman dengan orang lain, sebagai salah satu cara untuk berbagi perasaan dengan lingkungannya, serta membantu dalam meningkatkan wawasan. Pada jenjang pendidikan sekolah dasar (SD) penguasaan keterampilan bahasa termuat dalam pembelajaran Bahasa Indonesia. Keterampilan berbahasa yang dipelajari oleh seorang siswa dalam pembelajaran Bahasa Indonesia mencakup empat aspek, yaitu: menyimak, berbicara, membaca, dan menulis (Sarwiji, 2008: 2). Keempat keterampilan berbahasa ini memiliki keterhubungan yang erat satu sama lain dan diajarkan pada siswa secara sistematis sesuai dengan tahap berpikir mereka, mulai dari keterampilan menyimak, keterampilan berbicara, keterampilan membaca, hingga keterampilan menulis (Tarigan, 2008: 1). Keterampilan berbahasa pertama yang dipelajari oleh seorang siswa adalah keterampilan menyimak. Siswa biasanya mempelajari keterampilan menyimak saat duduk di kelas bawah dengan berlatih mendengarkan penjelasan dari guru. Melalui kemampuan menyimak yang baik seorang siswa mampu dengan mudah menyerap berbagai informasi baru.

Keterampilan berbahasa selanjutnya yang diajarkan adalah keterampilan berbicara, keterampilan berbicara membantu siswa dalam hal mengungkapkan segala gagasan serta isi pikiran yang ia miliki secara lisan. Setelah itu barulah ia mempelajari keterampilan membaca, yaitu suatu keterampilan untuk menemukan informasi yang terdapat dari suatu tulisan maupun sumber bacaan tertentu. Keterampilan menulis adalah keterampilan terakhir yang dipelajari siswa sekaligus merupakan keterampilan berbahasa yang paling rumit. Menulis menjadi keterampilan berbahasa yang paling rumit karena siswa harus mengolah gagasan dan pesan yang ingin disampaikan dengan melibatkan penyusunan kata, kalimat, hingga paragraf yang padu sehingga menjadi sebuah tulisan yang baik.

Hasil pengambilan data awal yang dilakukan di kelas V UPT. SD Negeri 04 Saruaso menunjukkan bahwa keterampilan menulis merupakan keterampilan yang penguasaanya paling rendah dibanding keterampilan berbahasa lainnya. Kenyataan ini diketahui berdasarkan wawancara dan observasi yang dilakukan dengan guru dan siswa di kelas tersebut. Guru menuturkan bahwa keterampilan menulis masih sulit dicapai oleh siswa, hal ini sesuai dengan pernyataan para siswa di kelas tersebut yang mengatakan bahwa keterampilan menulis dirasa sulit untuk dikuasai.Pernyataan dari guru dan siswa tersebut sejalan dengan penjelasan Mulyati (2007: 1.13), "menulis dikatakan suatu keterampilan berbahasa yang paling rumit di antara jenis aspek bahasa yang lainnya". Keterampilan menulis disebut sebagai tingkatan keterampilan berbahasa yang paling rumit dibandingkan aspek bahasa yang lain karena EISSN 2657-0289 Lembaga Penelitian dan Penerbitan Hasil Penelitian Ensiklopedia $\quad 25$ 
saat melakukan kegiatan menulis siswa dituntut untuk mampu menuangkan isi pemikirannya dengan struktur tulisan dan tata bahasa yang baik, mampu memilih kosakata-kosakata yang tepat dan sesuai, serta memperhatikan kaidah penulisan yang benar. Selain itu kemampuan siswa dalam menulis mempunyai andil yang penting dalam kegiatan mengikuti pembelajaran di kelas.

Pada jenjang pendidikan sekolah dasar keterampilan menulis dimaksudkan agar para siswa mampu menguasai kegiatan menulis dari tingkat menulis permulaan hingga mampu mencapai keterampilan menulis yang lebih tinggi layaknya kegiatan mengarang. Gie (1992: 17) menyatakan bahwa aktivitas mengarang adalah keseluruhan rangkaian kegiatan seseorang mengungkapkan gagasan dan menyampaikannya melalui bahasa tulis kepada pembaca untuk dipahami. Sehubungan dengan hal itu maka aktivitas mengarang yang dilakukan oleh seorang siswa dapat diartikan sebagai suatu keseluruhan rangkaian kegiatan yang dilakukan oleh seseorang untuk mengungkapkan gagasan dan menyampaikannya melalui bahasa tulis kepada pembaca untuk dipahami secara tepat seperti yang dimaksudkan oleh penulis.

Jenis karangan terbagi ke dalam beberapa bentuk yakni karangan deskripsi, karangan narasi, karangan argumentasi, karangan eksposisi, serta karangan persuasi. Pada jenjang kelas $\mathrm{V}$ sekolah dasar, jenis karangan yang dipelajari adalah jenis karangan deskripsi, karangan narasi, dan karangan eksposisi. Suparno \& Yunus (2009: 1.11-1.13) menyatakan bahwa karangan deskripsi adalah karangan yang melukiskan atau menggambarkan sesuatu berdasarkan pengamatan penulisnya, selanjutnya karangan narasi adalah karangan berisi proses kejadian suatu peristiwa yang disusun secara kronologis, sedangkan karangan eksposisi merupakan jenis karangan yang menjelaskan suatu hal atau objek yang bertujuan agar orang lain mengetahuinya.

Fakta di lapangan menunjukkan bahwa keterampilan menulis karangan narasi pada siswa kelas V UPT. SD Negeri 04 Saruaso masih tergolong rendah dibandingkan dengan keterampilan menulis karangan lainnya. Hal ini dapat diketahui dari hasil observasi kelas, serta pengamatan terhadap hasil karangan narasi. Karangan narasi dianggap paling rumit bagi siswa karena dalam penulisannya siswa harus memperhatikan urutan terjadinya peristiwa dalam isi karangan tersebut. Karangan narasi juga melibatkan adanya alur, latar, serta tokoh cerita yang sebagian besar siswa di kelas tersebut masih kesulitan dalam menuliskannya menjadi karangan yang utuh.

Selain itu, terdapat banyak permasalahan penulisan karangan narasi yang ditemui di kelas ini yaitu: kesalahan dalam penggunaan EYD, terlalu banyak adanya pengulangan kata, kurangnya penguasaan kosakata, penulisan kata yang tidak lengkap, kesulitan dalam menuangkan gagasan atau isi pikiran, dan ditemukan pula adanya kesulitan dalam mengembangkan bahasa serta memvariasikan kata dalam suatu karangan yang mereka tulis. Menurut wawancara yang dilakukan peneliti dengan para siswa, sebagian besar dari mereka menuturkan bahwa kegiatan menulis merupakan suatu hal yang dianggap sukar sekaligus membosankan. Hal ini diperkuat dari hasil pengambilan data awal tentang keterampilan menulis karangan siswa. Keterampilan siswa dalam menulis karangan narasi menempati posisi terendah dibandingkan dengan keterampilan siswa dalam menulis jenis karangan lainnya.

Berdasarkan pemaparan di atas, peneliti tergerak untuk mengadakan penelitian tindakan kelas dengan judul "Upaya Meningkatkan Keterampilan Menulis Karangan Narasi Melalui Metode Quantum Writing pada Siswa Kelas V UPT. SD Negeri 04 Saruaso".Berdasarkan uraian latar belakang di atas, maka dapat diidentifikasi 
beberapa masalah sebagai berikut: 1) Keterampilan menulis karangan narasi siswa kelas V UPT. SD Negeri 04 Saruaso masih rendah; 2) Nilai rata-rata menulis karangan narasi berada di bawah rata-rata kelas yaitu hanya mencapai 68,39. Berdasarkan diagnosis permasalahan di atas, maka ditemukan banyak permasalahan yang perlu dibahas dan dikaji lebih lanjut. Namun untuk memperdalam data yang dihasilkan maka penelitian ini difokuskan pada permasalahan rendahnya keterampilan menulis karangan narasi siswa kelas V UPT. SD Negeri 04 Saruaso.

\section{B. Metodologi Penelitian}

Desain penelitian yang dilakukan oleh peneliti merupakan penelitian berbasis tindakan kelas atau yang biasa disebut dengan PTK. Penelitian tindakan kelas berisi tentang suatu tindakan yang ditempuh oleh guru maupun tenaga pendidik lainnya dengan mengorganisasikan kondisi praktik pembelajaran mereka, dan belajar dari pengalaman mereka sendiri. Penelitian tindakan kelas dilakukan dengan tujuan untuk memperbaiki kualitas proses dan hasil belajar para peserta didik. Di dalam hal ini pembelajaran tidak terbatas pada pembelajaran yang dilakukan di ruang kelas tetapi lebih pada adanya aktivitas belajar dua orang atau lebih peserta didik (Mulyasa, 2016:10). Pendapat lain juga diungkapkan oleh Suharsimi (2007: 3) yang menyebutkan bahwa penelitian tindakan kelas adalah sebuah perencanaan terhadap kegiatan belajar berupa sebuah tindakan, yang sengaja dimunculkan dan terjadi dalam sebuah kelas secara bersama-sama. Di dalam penelitian ini peneliti bekerjasama dengan guru kelas untuk mengkaji permasalahan tentang rendahnya keterampilan menulis karangan narasi pada siswa kelas V UPT. SD Negeri 04 Saruaso. Penelitian dilakukan melalui kolaborasi guru kelas V dengan peneliti. Guru kelas V berperan sebagai pengajar, sedangkan peran teman sejawat sebagai observer yang membantu membuat Rencana Pelaksanaan Pembelajaran (RPP), mendesain perlengkapan pembelajaran, sekaligus membantu dalam proses pembelajaran. Desain tindakan penelitian ini didasarkan pada model spiral Kemmis \& Mc Taggart. Model ini merupakan pengembangan dari konsep dasar yang diperkenalkan oleh Kurt Lewin, hanya saja komponen tindakan dengan pengamatan dijadikan sebagai suatu kesatuan karena keduanya merupakan kegiatan yang tidak terpisahkan. Model Kemmis \& McTaggart terdiri dari empat komponen, yaitu: perencanaan, tindakan, observasi, pengamatan, dan refleksi. Keempat komponen tersebut merupakan suatu kesatuan yang membentuk siklus. Siklus merupakan putaran kegiatan yang terdiri dari perencanaan, tindakan, pengamatan, serta refleksi dan revisi Kusuma (2010: 20-21). Penelitian ini dilaksanakan di kelas V UPT. SD Negeri 04 Saruaso Kecamatan Tanjung Emas Kabupaten Tanah Datar. Kondisi lingkungan di sekitar sekolah dasar ini kondusif untuk melakukan kegiatan pembelajaran. Fasilitas yang disediakan di sekolah dasar ini juga sudah baik, hal ini terlihat dari adanya infrastruktur sekolah yang disediakan layaknya perpustakaan sekolah, lapangan upacara sekolah, kantin, ruang kelas yang memadahi, serta berbagai fasilitas yang lain. Subjek penelitian merupakan suatu sifat maupun keadaan yang akan diteliti berdasarkan kriteria-kriteria tertentu. Di dalam subjek penelitian ini terdapat sesuatu yang di dalamnya melekat hal-hal yang ingin dijadikan bahan penelitian. Penelitian tindakan kelas (PTK) ini mengambil subjek siswa kelas V UPT. SD Negeri 04 Saruaso Kecamatan Tanjung Emas berjumlah 23 siswa yang terdiri atas 13 siswa perempuan dan 10 siswa laki-laki. 


\section{Hasil Dan Pembahasan Deskripsi Kondisi Awal}

Pada tahap pra tindakan juga dilakukan adanya tes keterampilan menulis. Tes tersebut dilakukan untuk mengetahui tingkat keterampilan siswa dalam menulis karangan narasi. Di dalam tahap pra tindakan ini diketahui bahwa banyak siswa yang belum mampu mengembangkan gagasannya menjadi karangan yang baik. Hal ini diketahui dari banyaknya siswa yang kesulitan dalam menentukan ide awal tulisan. Selain itu masih banyak ditemui kesalahan penulisan layaknya penggunaan huruf kapital yang kurang tepat, penggunaan ejaan yang kurang tepat, pemilihan kata yang tidak baku, serta paragraf kurang dikembangkan dengan baik. Hasil karangan narasi pada tahap pra tindakan ini selanjutnya dianalisis menggunakan pedoman penilaian keterampilan menulis karangan menurut Rofi'udin dan Zuhdi (1999: 273) dengan penyesuaian seperlunya untuk mengetahui pencapaian nilai keterampilan karangan narasi masing- masing siswa. Menurut hasil analisis yang dilakukan pada hasil karangan siswa, ternyata masih banyak siswa yang mendapatkan nilai di bawah rata- rata 75 . Berikut adalah nilai hasil menulis siswa saat pembelajaran karangan pada saat pra tindakan. Selengkapnya hasil nilai siswa pada pra tindakan dapat dilihat pada lampiran 1.

Tabel Daftar Nilai Pra Tindakan Menulis Karangan Narasi pada Siswa Kelas V

\begin{tabular}{|c|c|c|c|c|}
\hline No & Nama Peserta Didik & Nilai & Tuntas & Tidak Tuntas \\
\hline 1 & Rayhan Julian & 63 & & $\sqrt{ }$ \\
\hline 2 & Alfitrah Rizky Rahmadani & 62 & & $\sqrt{ }$ \\
\hline 3 & Zacky Kurniawan & 70 & & $\sqrt{ }$ \\
\hline 4 & Alam Dewatra Sarkup & 76 & $\sqrt{ }$ & \\
\hline 5 & Chelsea Agustia & 81 & & $\sqrt{ }$ \\
\hline 6 & Fajra Salsabila & 60 & & $\sqrt{ }$ \\
\hline 7 & Fajar Ramadhan & 55 & & $\sqrt{ }$ \\
\hline 8 & Farhan Ahmad Febrian & 65 & & $\sqrt{ }$ \\
\hline 9 & Fhika Amelia Putri & 80 & $\sqrt{ }$ & \\
\hline 10 & Ghezika Melody & 66 & & $\sqrt{ }$ \\
\hline 11 & Indra & 76 & $\sqrt{ }$ & \\
\hline 12 & Mayang Putri Rindiani & 75 & $\sqrt{ }$ & $\sqrt{ }$ \\
\hline 13 & Rangga Saputra & 60 & & $\sqrt{ }$ \\
\hline 14 & Revan Perta Maisyah & 61 & & $\sqrt{ }$ \\
\hline 15 & Romako Putra Ahmad & 63 & & $\sqrt{ }$ \\
\hline 16 & Salsa Mahenda & 68 & & $\sqrt{ }$ \\
\hline 17 & Santi Wulandari & 76 & $\sqrt{ }$ & \\
\hline 18 & \begin{tabular}{|l} 
Zahrani Adha \\
\end{tabular} & 60 & & $\sqrt{ }$ \\
\hline 19 & Zahwa Khoiri & 75 & $\sqrt{ }$ & \\
\hline 20 & Jihan Aulia & 65 & & $\sqrt{ }$ \\
\hline $21^{2}$ & Haisyah Hasnadiva G.A & 62 & $\sqrt{ }$ & \\
\hline 22 & Mukhlis Akbar & 75 & $\sqrt{ }$ & \\
\hline 23 & Aulia Sabrina & 79 & $\sqrt{ }$ & \\
\hline \multicolumn{2}{|c|}{ Jumlah } & 1573 & & 4 \\
\hline \multicolumn{2}{|c|}{ Rata - rata nilai } & 68,39 & & \\
\hline \multicolumn{3}{|c|}{ Persentase Ketuntasan } & $13 \%$ & $37 \%$ \\
\hline
\end{tabular}

Hasil karangan siswa pada tes pra tindakan ini menunjukkan bahwa hanya terdapat $9(39,13 \%)$ siswa yang nilainya mencapai rata-rata 75, sedangkan 14 $(60,87 \%)$ siswa masih memiliki nilai di bawah rata-rata, serta perolehan rata-rata kelas adalah 68,39. Berdasarkan hasil pembelajaran pada tahap pra tindakan ini dapat disimpulkan bahwa keterampilan menulis siswa masih rendah dan perlu untuk 
ditingkatkan. Selain perolehan nilai yang rendah pada pembelajaran menulis karangan, sebagian besar siswa juga kurang tertarik dengan pembelajaran menulis, dan partisipasi siswa dalam pembelajaran masih kurang. Hal ini dapat terlihat dari beberapa siswa yang lebih memilih untuk mengobrol dengan teman maupun melamun saat pembelajaran menulis berlangsung.

Berdasarkan hal-hal di atas, peneliti dan guru kelas sepakat untuk menyelenggarakan penelitian tindakan kelas pada siswa kelas V UPT. SD Negeri 04 Saruaso. Tindakan yang ditempuh untuk meningkatkan keterampilan narasi siswa adalah dengan menerapkan metode quantum writing. Melalui metode ini diharapkan siswa dapat lebih antusias dan berpartisipasi aktif dalam pembelajaran menulis karangan, sehingga dapat meningkatkan keterampilan menulis karangan narasi siswa

\section{Deskripsi Hasil penelitian Siklus I}

Berikut adalah hasil pencapaian siswa dalam menulis karangan narasi pada siklus I.

Tabel Daftar Nilai Pra Tindakan dan Siklus I Menulis Karangan Narasi pada Siswa Kelas V

\begin{tabular}{|l|l|l|l|}
\hline Np & Nama Peserta Didik & Pra Siklus & Siklus I \\
\hline 1 & Rayhan Julian & 63 & 63 \\
\hline 2 & Alfitrah Rizky Rahmadani & 62 & 76 \\
\hline 3 & Zacky Kurniawan & 70 & 70 \\
\hline 4 & Alam Dewatra Sarkun & 76 & 77 \\
\hline 5 & Chelsca Agustia & 81 & 83 \\
\hline 6 & Fajra Salsabila & 60 & 69 \\
\hline 7 & Fajar Ramadhan & 55 & 65 \\
\hline 8 & Farhan Ahmad Febrian & 65 & 77 \\
\hline 9 & Ehika Amelia Putri & 80 & 83 \\
\hline 10 & Ghezika Melody & 66 & 65 \\
\hline 11 & Indra & 76 & 76 \\
\hline 12 & Mayang Putri Rindiani & 75 & 78 \\
\hline 13 & Rangga Saputra & 60 & 68 \\
\hline 14 & Revan Perta Maisyah & 61 & 71 \\
\hline 15 & Bomaka Putra Ahmad & 63 & 79 \\
\hline 16 & Salsa Mahenda & 68 & 79 \\
\hline 17 & Santi Wulandari & 76 & 81 \\
\hline 18 & Zahrani Adha & 60 & 65 \\
\hline 19 & Zahwa Khoiri & 75 & 82 \\
\hline 20 & Jihan Aulia & 65 & 75 \\
\hline 21 & Haisvah Hasnadiva G.A & 62 & 80 \\
\hline 22 & Mukhlis Akbar & 75 & 75 \\
\hline 23 & Aulia Sabrina & 79 & 82 \\
\hline Jumlah & 1573 & 1719 & \\
\hline Nilai rata - rata & 68,39 & 74,74 & \\
\hline Siswa yang tuntas & 9 & 15 & \\
\hline Siswa tidak tuntas & 14 & 8 & \\
\hline Tingkat ketuntasan & $39,13 \%$ & $65,22 \%$ & \\
\hline
\end{tabular}

Berdasarkan hasil karangan siswa pada siklus I tersebut diketahui bahwa terdapat $26(68,42 \%)$ siswa yang nilainya mencapai rata-rata 75 , sedangkan 12 siswa $(31,58 \%)$ siswa masih memiliki nilai di bawah rata-rata, serta perolehan rata-rata kelas adalah 75,68. Hal ini menunjukkan bahwa terdapat peningkatan nilai rata-rata EISSN 2657-0289 Lembaga Penelitian dan Penerbitan Hasil Penelitian Ensiklopedia $\quad 29$ 
dari hasil karangan siswa. Peningkatan pencapaian nilai rata-rata pada siswa kelas $\mathrm{V}$ UPT. SD Negeri 04 Saruaso pada siklus I dapat diketahui melalui gambar diagram lingkaran di bawah ini.

Gambar diagram batang di atas menunjukkan bahwa terdapat adanya peningkatan rata-rata hasil menulis karangan narasi siswa yang sebelumnya pada pra tindakan adalah 68,39 meningkat menjadi 74,74 pada siklus I. Meskipun demikian, jumlah siswa yang sudah memperoleh nilai di atas rata- rata 75 baru mencapai 15 $(65,22 \%)$ siswa. Padahal, kriteria keberhasilan dari penelitian ini adalah apabila nilai rata-rata siswa dalam menulis karangan narasi mencapai rata-rata $\geq 75$ dengan tingkat ketuntasan $\geq 75 \%$ dari jumlah keseluruhan siswa kelas V.

\section{Deskripsi Hasil penelitian Siklus II}

Hasil karangan siswa memperlihatkan bahwa hanya ditemukan sebagian kecil kesalahan penulisan dalam beberapa karangan narasi siswa. Hal ini membuktikan bahwa keterampilan menulis siswa semakin meningkat. Pencapaian nilai keterampilan siswa dalam pembelajaran menulis karangan narasi juga semakin meningkat, seperti pada tabel yang dapat dilihat di bawah ini

\section{Tabel Daftar Nilai Pra Tindakan, Siklus I, dan Siklus II dalam Menulis Karangan} Narasi

\begin{tabular}{|l|l|l|l|l|}
\hline No & Nama Peserta Didik & Pra Siklus & Siklus I & Siklus II \\
\hline 1 & Rayhan Julian & 63 & 63 & 70 \\
\hline 2 & Alfitrah Rizky Rahmadani & 62 & 76 & 80 \\
\hline 3 & Zacky Kurniawan & 70 & 70 & 84 \\
\hline 4 & Alam Dewatra Sarkup & 76 & 77 & 86 \\
\hline 5 & Chelsea Agustia & 81 & 83 & 94 \\
\hline 6 & Fajra Salsabila & 60 & 69 & 74 \\
\hline 7 & Fajar Ramadhan & 55 & 65 & 78 \\
\hline 8 & Farhan Ahmad Febrian & 65 & 77 & 82 \\
\hline 9 & Fhika Amelia Putri & 80 & 83 & 92 \\
\hline 10 & Ghezika Melody & 66 & 65 & 80 \\
\hline 11 & Indra & 76 & 76 & 80 \\
\hline 12 & Mayang Putri Rindiani & 75 & 78 & 84 \\
\hline 13 & Rangga Saputra & 60 & 68 & 75 \\
\hline 14 & Revan Perta Maisyah & 61 & 71 & 76 \\
\hline 15 & Romako Putra Ahmad & 63 & 79 & 84 \\
\hline 16 & Salsa Mahenda & 68 & 79 & 86 \\
\hline 17 & Santi Wulandari & 76 & 81 & 79 \\
\hline 18 & Zahrani Adha & 60 & 65 & 71 \\
\hline 19 & Zahwa Khoiri & 75 & 82 & 87 \\
\hline 20 & Jihan Aulia & 65 & 75 & 76 \\
\hline 21 & Haisyah Hasnadiva G.A & 62 & 80 & 88 \\
\hline 22 & Mukhlis Akbar & 75 & 75 & 87 \\
\hline 23 & Aulia Sabrina & 79 & 82 & 91 \\
\hline Jumlah & 1573 & 1719 & 1884 \\
\hline Nilai Rata-Rata & 68,39 & 74,74 & 81,91 \\
\hline Siswa Tuntas & 9 & 15 & 20 \\
\hline Siswa Tidak Tuntas & 14 & 8 & 3 \\
\hline Tingkat Ketuntasan & $39,13 \%$ & $65,22 \%$ & $86,96 \%$ \\
\hline
\end{tabular}


Berdasarkan hasil karangan siswa pada siklus II tersebut diketahui bahwa terdapat $20(86,96 \%)$ siswa yang nilainya sudah mencapai rata-rata 75 , sedangkan perolehan rata-rata kelas adalah 81,91. Hal ini menunjukkan bahwa terdapat peningkatan nilai rata-rata dari hasil karangan narasi siswa. Peningkatan nilai rata-rata pada siswa kelas V UPT. SD Negeri 04 Saruaso Kecamatan Tanjung Emas Kabupaten Tanah Datar pada siklus II juga dapat dilihat melalui gambar di bawah ini.

Gambar diagram batang di atas menunjukkan bahwa terdapat adanya peningkatan nilai rata-rata hasil menulis karangan narasi siswa yang sebelumnya pada siklus I adalah 74,74 meningkat menjadi 81,91 pada siklus II. Ketuntasan siswa pada akhir siklus II mencapai 86,96\%. Peningkatan keterampilan menulis karangan narasi siswa dengan menerapkan metode quantum writing telah mencapai tujuan yang diharapkan, yaitu nilai rata-rata siswa dalam menulis karangan narasi mencapai ratarata $\geq 75$ dengan tingkat ketuntasan $\geq 75 \%$ dari jumlah keseluruhan siswa.

Selain itu, siswa juga semakin aktif dan terlibat langsung dalam kegiatan pembelajaran. Hal ini dapat diketahui dari hasil observasi terhadap kegiatan siswa pada pembelajaran menulis karangan narasi pada siklus II. Hasil observasi menunjukkan adanya peningkatan yang signifikan pada aktivitas guru dan siswa terhadap tahapan yang direncanakan dalam pembelajaran menggunakan metode quantum writing.

Siswa juga semakin terlibat aktif dalam pembelajaran, hal ini dapat diketahui dari hasil observasi terhadap kegiatan siswa pada pembelajaran menulis karangan narasi pada siklus II. Aktivitas siswa dalam pembelajaran pada siklus I sebesar $72,78 \%$ dan meningkat menjadi $87,78 \%$ pada siklus II. Oleh karena itu dapat diketahui bahwa sudah terdapat adanya peningkatan partisipasi aktif siswa dalam kegiatan pembelajaran. Berdasarkan pencapaian tersebut, maka pembelajaran dalam penelitian ini sudah dianggap berhasil. Peneliti dan observer sepakat untuk mengakhiri penelitian tindakan kelas pada siklus II dan tidak dilanjutkan pada siklus selanjutnya.

\section{Pembahasan}

\section{Peningkatan Proses Keterampilan Menulis Karangan Narasi}

Berdasarkan pengamatan yang dilakukan pada kondisi awal keterampilan menulis karangan narasi siswa kelas V UPT. SD Negeri 04 Saruaso Kecamatan Tanjung Emas Kabupaten Tanah Datar masih tergolong rendah. Hal ini dapat dibuktikan dengan pencapaian nilai rata-rata siswa dalam menulis karangan narasi yang masih banyak di bawah rata-rata dengan nilai 75 . Siswa yang memperoleh nilai $\geq 75$ baru mencapai 9 orang yang bahkan belum mencapai setengah dari keseluruhan jumlah siswa di kelas tersebut. Di samping hal itu, siswa juga kurang tertarik dengan pembelajaran menulis. Hal ini dapat dibuktikan dengan hasil wawancara yang dilakukan oleh peneliti kepada siswa yang menyatakan bahwa pembelajaran menulis dianggap sebagai pembelajaran yang lebih rumit dibanding pembelajaran lain.

Kurangnya ketertarikan siswa pada pembelajaran menulis lebih banyak dikarenakan kegiatan pembelajaran yang dilakukan di kelas bersifat monoton. Pembelajaran yang guru lakukan di dalam kelas hanya menggunakan metode konvensional tanpa divariasikan dengan metode pembelajaran yang sesuai dengan kebutuhan siswa. Siswa juga kurang aktif dalam mengikuti pembelajaran menulis karena pembelajaran ini dianggap sebagai pembelajaran yang membosankan. Pada awal pertemuan bahkan masih tampak beberapa siswa yang ramai sendiri dengan temannya maupun kurang fokus dengan materi yang disampaikan guru karena merasa kurang antusias dengan pembelajaran menulis. 
Pada pembelajaran menggunakan cara konvensional ini siswa hanya diberikan tema tertentu, kemudian siswa langsung diminta untuk menuliskan sebuah karangan. Guru tidak menjelaskan secara rinci pada siswa tentang cara membuat kerangka karangan yang tepat maupun cara yang dilakukan untuk mengembangkan kerangka karangan tersebut menjadi karangan yang padu. Hal inilah yang membuat siswa merasa pembelajaran menulis adalah suatu pembelajaran yang rumit dan sulit untuk dilakukan. Kenyataan ini pula yang kemudian menyebabkan banyak siswa yang hanya mampu menulis karangan narasi dalam bentuk yang pendek dan gagasan kurang dikembangkan secara luas. Selain itu, siswa tidak mendapat kesempatan untuk memperoleh bimbingan maupun penguatan pada materi pembelajaran menulis. Hal tersebut mengakibatkan banyak siswa yang masih sering melakukan kesalahan penulisan layaknya kesalahan dalam penulisan ejaan kata, kesalahan dalam pemilihan tanda baca, banyak kata penghubung yang ditulis secara berulang, penempatan huruf kapital yang tidak sesuai dalam kalimat, pemenggalan kata yang tidak sesuai, pembentukan kalimat yang kurang tepat, jarak spasi antar kata yang terlalu jauh maupun terlalu dekat, kesalahan dalam pembentukan kalimat, serta masih adanya kesulitan dalam mengembangkan gagasan awal menjadi suatu karangan yang utuh dan lengkap.

Keterampilan menulis siswa dapat lebih ditingkatkan dengan menerapkan adanya pembelajaran yang tepat dan dapat memberikan kebermanfaatan bagi siswa. Siswa semakin menguasai keterampilan menulis dengan adanya kegiatan yang memungkinkan mereka untuk terlibat secara aktif dalam pembelajaran dan lebih percaya diri dalam mempelajari hal-hal yang baru. Hal ini sesuai dengan tujuan pembelajaran menggunakan metode quantum writing menurut Arifin \& Setiyawan (2012: 8), yaitu tujuan dari metode quantum writing ini adalah agar seorang siswa merasa nyaman keluar dari zona nyamannya untuk mempelajari sesuatu yang baru. Oleh karena itu siswa yang terlibat aktif dalam pembelajaran akan lebih mudah dalam mengkonstruksi pemahaman yang telah dimiliki sebelumnya dengan pengetahuanpengetahuan baru yang ia dapatkan.

Keterampilan menulis karangan pada siswa dapat lebih dioptimalkan melalui pengubahan cara belajar yang tepat bagi siswa serta dengan menciptakan lingkungan belajar yang efektif. Pernyataan ini sesuai dengan tujuan pembelajaran metode quantum writing yang dikemukakan oleh A'la (2011: 18), bahwa pembelajaran quantum writing bermaksud dalam memaksimalkan usaha pengajaran guru melalui pengubahan cara belajar, menciptakan lingkungan belajar yang efektif, menyampaikan suatu isi pembelajaran, serta memudahkan proses belajar. Cara belajar yang tepat akan membantu siswa dalam memahami suatu pengetahuan maupun keterampilan yang diajarkan oleh guru.

Proses pembelajaran menggunakan metode quantum writing ternyata menunjukkan adanya peningkatan keaktifan siswa dalam pembelajaran. Hal ini dapat diketahui dari adanya peningkatan persentase terhadap aktivitas siswa dari pra tindakan ke siklus I, dan dari siklus I ke siklus II. Hasil observasi memperlihatkan bahwa aktivitas siswa dalam pembelajaran meningkat. Pada siklus I tingkat keaktifan siswa sebesar $72,78 \%$, kemudian meningkat menjadi $87,78 \%$ pada siklus II. Pada saat pembelajaran menulis karangan narasi menggunakan metode ini, suasana kelas menjadi lebih hidup dengan adanya keterlibatan aktif siswa. Siswa menjadi lebih termotivasi untuk mengikuti pembelajaran karena guru memberikan kesempatan bagi siswa untuk bertanya maupun untuk mengemukakan 
pendapatnya. Siswa juga semakin antusias dengan pembelajaran menulis karena mereka turut terlibat secara aktif dalam memberikan umpan balik karangan, dapat mengetahui kesalahan tulis yang ia lakukan, serta dapat menyunting tulisannya menjadi lebih baik.

Pelaksanaan pembelajaran juga dapat berjalan dengan optimal dengan adanya peran guru sebagai fasilitator sekaligus pemberi arahan bagi para siswa. Adanya tambahan umpan balik dari guru serta pemberian penguatan bagi siswa yang masih mengalami kesulitan pembelajaran membuat jalannya pembelajaran menjadi lebih maksimal. Apresiasi berupa pujian turut diberikan oleh guru sebagai cara memotivasi siswa untuk lebih fokus dalam mengikuti pembelajaran. Siswa menjadi tidak mudah bosan selama mengikuti pembelajaran serta menjadi lebih percaya diri untuk berpartisipasi aktif dalam pembelajaran. Metode quantum writing dalam pembelajaran menulis memudahkan siswa mengembangkan gagasan awal karangan menjadi karangan narasi yang baik serta membantu membiasakan siswa menulis sesuai dengan kaidah yang berlaku. Hal tersebut dapat diperoleh dengan mengarahkan siswa untuk keluar dari kebiasan melakukan penulisan yang salah dan memperbaiki kebiasan tersebut dengan mempelajari sesuatu yang baru. Oleh karena itu metode ini menekankan pada pembelajaran yang berpusat pada siswa sebagai subjek yang turut terlibat aktif dalam proses pembelajaran.

Pembelajaran ini lebih berpusat pada siswa, sehingga siswa akan secara aktif terlibat dalam kegiatan pembelajaran. Hal ini sesuai dengan kajian teori menurut DePorter \& Hernacki (2006: 195) yang menyebutkan bahwa siswa melakukan kegiatan persiapan menulis, membuat draft/kerangka karangan, berbagi hasil tulisan dengan teman, memperbaiki kesalahan penulisan, menyunting hasil tulisan, menulis kembali karangan, serta melakukan evaluasi hasil tulisan sebagai penerapan dari metode quantum writing. Penggunaan metode quantum writing membantu siswa dalam mengenali kesalahan tulis yang sering dilakukan sekaligus memotivasi siswa agar mampu mengembangkan gagasan dalam tulisannya dengan optimal.

\section{Peningkatan Hasil Keterampilan Menulis Karangan Narasi}

Penelitian tindakan kelas dalam upaya meningkatkan keterampilan menulis karangan narasi menggunakan metode quantum writing ini telah mencapai kriteria keberhasilan. Hal ini diketahu dari hasil siklus II yang menunjukkan bahwa sebanyak $20(86,96 \%)$ siswa atau lebih dari $75 \%$ siswa telah mencapai nilai rata-rata 75 yang telah ditentukan oleh sekolah. Berdasarkan hal tersebut, maka penelitian ini dianggap berhasil dan selanjutnya penelitian dihentikan pada siklus II. Penerapan metode quantum writing pada pembelajaran menulis karangan narasi pada siswa kelas V UPT. SD Negeri 04 Saruaso Kecamatan Tanjung Emas Kabupaten Tanah Datar sudah menunjukkan adanya peningkatan yang signifikan pada hasil karangan narasi siswa. Hal ini sesuai dengan salah satu manfaat pembelajaran quantum writing yang disebutkan oleh Siregar \& Nara (2011: 80) yang menyebutkan bahwa quantum writing bermanfaat dalam menciptakan lingkungan belajar yang efektif, dengan cara menggunakan unsur yang ada pada siswa dan lingkungan belajarnya melalui interaksi yang terjadi di dalam kelas. Penerapan metode ini mendorong siswa untuk berinteraksi dengan teman maupun guru saat pembelajaran menulis berlangsung sehingga mampu mengoptimalkan penguasaan keterampilan menulis siswa.

Menurut hasil penelitian yang telah dilakukan, dapat diketahui bahwa terjadi peningkatan keterampilan menulis dari kondisi awal pencapaian nilai rata-rata siswa 
68,39 meningkat menjadi 74,74 pada siklus I dan mencapai rata-rata 81,91 pada siklus II. Tingkat ketuntasan siswa dalam menulis karangan narasi turut mengalami perubahan dari kondisi awal 39,13\% menjadi $65,22 \%$ pada siklus I dan meningkat menjadi $86,96 \%$ pada siklus II. Hasil penelitian ini sesuai dengan pendapat Hernowo (2003: 10) yang menyatakan bahwa quantum writing adalah interaksi dalam proses belajar menulis yang mampu mengubah berbagai potensi menulis yang ada di dalam diri seseorang, Selain mampu memberikan peningkatan terhadap pencapaian keterampilan siswa dalam menulis karangan narasi, pembelajaran dengan metode ini mampu mengembangkan tingkat kekritisan siswa dalam menuliskan suatu karangan. Pernyataan ini sejalan dengan pemdapat DePorter \& Hernacki (2009: 12) yang mengungkapkan bahwa manfaat dari adanya metode quantum writing adalah mendorong penulis untuk kritis dan kreatif dalam menulis. Siswa menjadi tertarik untuk menuangkan gagasannya menjadi sebuah karangan yang berkembang, baik dari isi cerita yang semakin luas maupun dari sisi penulisan yang lebih sesuai dengan kaidah penulisan. Hal inilah yang nantinya akan membantu siswa untuk secara maksimal mengembangkan potensi menulis yang ada pada dirinya.

Peningkatan keterampilan menulis karangan narasi di kelas V UPT. SD Negeri 04 Saruaso Kecamatan Tanjung Emas Kabupaten Tanah Datar ini telah dianggap berhasil karena jumlah siswa yang mencapai nilai rata-rata ketuntasan 75 sudah melebihi $75 \%$ dari keseluruhan siswa dikelas tersebut. Meskipun demikian, masih terdapat $3(15,79 \%)$ siswa yang belum mencapai nilai rata-rata 75 dalam pembelajaran menulis karangan narasi. Peran guru akan sangat penting dalam menerapkan metode quantum writing ini dalam pembelajaran menulis secara berkelanjutan sehingga nantinya siswa dapat mencapai hasil yang maksimal. Guru juga berperan sebagai fasilitator, motivator, serta pembimbing dalam pelaksanaan pembelajaran yang melibatkan interaksi siswa saat pembelajaran menulis menggunakan metode quantum writing ini.

\section{Penutup}

Berdasarkan hasil penelitian tindakan kelas (PTK) yang dilaksanakan di kelas V UPT. SD Negeri 04 Saruaso Kecamatan Tanjung Emas Kabupaten Tanah Datar diperoleh kesimpulan sebagai berikut: 1) Upaya meningkatkan keterampilan menulis karangan narasi pada siswa kelas V UPT. SD Negeri 04 Saruaso Kecamatan Tanjung Emas Kabupaten Tanah Datar melalui metode quantum writing dilakukan dengan tahap-tahap kegiatan seperti persiapan menulis, membuat draft/kerangka karangan, berbagi hasil tulisan dengan teman, memperbaiki kesalahan penulisan, menyunting hasil tulisan, menulis kembali karangan, serta melakukan evaluasi hasil tulisan siswa; 2) Upaya meningkatkan keterampilan menulis karangan narasi pada siswa kelas V UPT. SD Negeri 04 Saruaso Kecamatan Tanjung Emas Kabupaten Tanah Datar melalui metode quantum writing menunjukkan keberhasilan. Hal ini ditunjukan dengan nilai rata-rata menulis karangan narasi siswa yang meningkat dari pra tindakan ke siklus I dan II. Peningkatan keterampilan menulis meningkat dari kondisi awal 68,39 menjadi 74,74 pada siklus I dan mencapai 81,91 pada siklus II. Tingkat ketuntasan siswa dalam menulis karangan narasi turut mengalami perubahan dari kondisi awal $39,13 \%$ menjadi $65,22 \%$ pada siklus I dan meningkat menjadi $86,96 \%$ pada siklus II. Selain itu siswa semakin antusias dan terlibat secara aktif dalam kegiatan pembelajaran. Hal ini diketahui dari aktivitas siswa dalam pembelajaran meningkat menjadi $72,78 \%$, pada siklus I dan meningkat menjadi 
87,78\% pada siklus II. Dengan demikian, penggunaan metode quantum writing dapat meningkatkan keterampilan menulis karangan narasi siswa kelas V UPT. SD Negeri 04 Saruaso Kecamatan Tanjung Emas Kabupaten Tanah Datar.

\section{Daftar Pustaka}

Abbas, S. (2006). Pembelajaran Bahasa Indonesia yang Efektif di Sekolah Dasar. Jakarta: Depdiknas.

Akbar, S., A'yun, I.Q., Satriyani, F.Y., et al. (2016). Implementasi Pembelajaran Tematik di Sekolah Dasar. Bandung: PT Remaja Rosda Karya.

Akhadiah, S., Arsjad, M.G., Ridwan, S.H., et al. (1991). Bahasa Indonesia II.

Jakarta: Departemen Pendidikan dan Kebudayaan. (1992). Bahasa Indonesia III. Jakarta: Departemen Pendidikan dan Kebudayaan.

A'la, M. (2011). Quantum Teaching. Yogyakarta: Diva Press.

Arifin, Z. \& Setiyawan, A. 2012. Pengembangan Pembelajaran Aktif dengan ICT. Yogyakarta: Skripta Media Creative.

De Porter, B. \& Hernacki, M. (2006). Quantum Learning: Membiasakan Belajar Nyaman dan Menyenangkan. Bandung: Kaifa. (2009). Quantum Learning. Bandung: Kaifa.

Gie, T.L. (1992). Pengantar Dunia Karang Mengarang. Yogyakarta: Liberty dan Balai Bimbingan Mengarang.

Hajar, I. (2013). Panduan Lengkap Kurikulum Tematik untuk SD/MI. Yogyakarta: Diva Press.

Hernowo. (2003). Quantum Writing. Bandung: Media Learning Center.

. (2004). Quantum Writing. Bandung: Media Learning Center.

Kusuma, W. (2010). Mengenal Penelitian Tindakan Kelas. Jakarta: PT. Indeks,

Mulyasa. (2016). Praktik Penelitian Tindakan Kelas. Bandung: PT Remaja Rosdakarya.

Mulyati. Y. (2007). Keterampilan Berbahasa Indonesia. Jakarta: Universitas Terbuka.

Nurgiyantoro, B. (2010). Penilaian dalam Pengajaran Bahasa dan Sastra. Yogyakarta: BPFE.

Nurhadi. (1995). Tata Bahasa Pendidikan. Semarang: IKIP Semarang Press.

Puji, F.P. (2010). Bahasa Indonesia untuk SD dan MI Kelas V Semester 2. Klaten: Intan Pariwara.

Rofi'udin, A. \& Zuhdi, D. (1999). Pendidikan Bahasa dan Sastra di Kelas

Tinggi. Jakarta: Departemen Pendidikan dan Kebudayaan.

Semi, M. (1990). Menulis Efektif. Padang: Angkasa Raya Padang.

Siregar, E. \& Nara, H. (2011). Teori Belajar dan Pembelajaran. Bogor: Ghalia Indonesia.

Suharsimi, A. (2007). Prosedur Penelitian Suatu Pendekatan Praktik. Jakarta: Rineka Cipta. Rineka Cipta.

Suparno \& Yunus, M. (2009). Keterampilan Dasar Menulis. Jakarta: Universitas Terbuka.

Suryaman, M. (2012). Metodologi Pembelajaran Bahasa. Yogyakarta: UNY Press.

Syafi'ie,.I. (1988). Retorika dalam Menulis. Jakarta: Departemen Pendidikan dan Kebudayaan 
Vol. 3 No.1 April 2021

Ensiklopedia Education Review

http://jurnal.ensiklopediaku.org

Tarigan, H.G. (2008). Strategi Pengajaran dan Pembelajaran Bahasa. Bandung: Angkasa.

Yaumi, M. (2014). Prinsip-Prinsip Desain Pembelajaran Disesuaikan dengan

Kurikulum 2013. Jakarta: Kencana Prenada Media Group. 